\title{
Parallel Mixed Mode Surveys on Consumer Attitude towards Fresh Produce
}

\author{
Fatimah Mohamed Arshad (Corresponding author) \\ Institute of Agricultural and Food Policy Studies), Infoport \\ Universiti Putra Malaysia, 43400 Serdang Selangor, Malaysia \\ Tel: 60-3-8947-1070 E-mail: fatimah@econ.upm.edu.my \\ Suryani Darham \\ Institute of Agricultural and Food Policy Studies), Infoport \\ Universiti Putra Malaysia, 43400 Serdang Selangor, Malaysia \\ Tel: 60-3-8947-1070_E-mail: suryani07@gmail.com
}

Received: July 19, 2010

Accepted: August 15, 2010

Online Published: August 27, 2012

doi:10.5430/bmr.v1n3p51

URL: http://dx.doi.org/10.5430/bmr.v1n3p51

The research is financed by the Federal Agricultural Marketing Authority of Malaysia (FAMA).

\begin{abstract}
This paper investigates the effect of parallel mixed mode surveys on findings of a study on the Malaysian consumers' attitude towards buying of fresh produce from the large retail stores. Two survey methods were employed, i.e., a face to face interview and an online survey with each required different sampling technique and questioning methods. Statistical tests such as t-test, and chi-square were used to detect mean differences. A factor analysis was run to elucidate the major salient factors that explain the consumers' choice on certain large scale retail stores for fresh produce. The findings suggest that despite the biases of each method and minor differences in results, both are complementary as each rectifies each other's weaknesses.
\end{abstract}

Keywords: Malaysia, Mixed mode survey, Consumer attitude, Fresh produce, Large scale retailers

\section{Introduction}

A study has been carried out to examine the Malaysian consumers' attitude towards the large scale retail stores (such as hypermarkets, supermarkets and departmental stores) for fresh produce using face to face interview and internet surveys to collect the necessary primary data. Like in any other developing countries, the advent of large scale multi-national retailers has changed the retail landscape in the country. Despite their late entry into the market (starting in the mid 1990s), they were able to secure about one third of the market share of the retail sales and accounted for about 35\% of fruits and vegetable sales in Malaysia in 2002 (FAO, 2005). Hence, it would be useful to examine the factors that push the consumers to purchase from their supplies of fresh produce (fruits and vegetables) from these new retailers despite the availability of many alternatives such as the conventional small shops around their neighborhood, farmers market and mobile market. In order to understand the consumer decision, one must obtain primary data from the consumers or the buyers who are largely females either housewives or professionals and workers. However, in view of their lifestyle, applying the face to face interview technique may not be able to cover those consumers who are at their work premises during the day. Hence a mixed-mode is deemed necessary to reach the two groups - the housewives as well as the workers at either their homes or work premises.

The study has chosen a mixed-mode survey comprised the face to face (FTF) and internet surveys method to solicit consumers' perception on the retailers and factors that affecting their decision to buy from the large retailers. The FTF technique was aimed largely at housewives who either stay at home while the internet was aimed at those who preferred to answer question through the internet. The decision to adopt both techniques was driven by the need to cover as many respondents as possible at an economic cost in accordance with the definition of research design made by Selltiz et al., (1962). Selltiz et al., defined research design as the "arrangement of conditions for collection of and 
analysis of data in a combine relevance to the research purpose with economy in procedure". Despite the possible biases of each of the techniques (Nesbary, 2000, Moss and Hendry, 2002), a combination of survey methods is acceptable (Payne, 1964). A combination of survey methods is perceived as complementary parts of a single investigation. In this study, the sampling procedure and the questionnaire design differed while the hypotheses and empirical analyses were similar. However, the medium used by the both method differed in that the FTF involved conversation between the interviewer and the respondent while the internet survey involved the respondent and the computer. Secondly, the times of the survey for the FTF interview were mostly during the day time while for the internet survey were 24/7. In view of these differences and other biases, this paper aims at analysing the effects of the two survey techniques, FTF interview and internet survey on the findings.

\section{Literature Review}

The comparison between the online survey and the conventional methods yield mixed results. The conventional face to face interview or "pencil and paper survey" has some well established advantages such as flexibility in questioning, low non-response items and higher degree of accuracy (Zikmund, 2003,). Its weaknesses include; falling participation rates, rising costs, labour intensive and limited coverage (Jarvis, 2002).

The evaluation on the online survey received mix viewpoints. A number of claimed advantages were put forward such as lower cost, faster turnaround, bigger coverage of samples, minimum researcher's time and resources, convenient time and location for subjects, anonymity for researchers and subjects, higher response levels, lower respondent error, inexpensive, and possibility of multi media usage on the internet page (Davis, 1999; Dillman 2000; Forrest, 1999; Moss and Hendry, 2002; and Solomon, 2001). In short, online method as a data collection is considered efficient (Weible and Wallace and Kaye and Johnson, 1999).

Critics pointed out that internet-research participants are self-selected group, hardly comprising a random sample (Petit, 1999). A number of studies have evaluated the differential effects of online and traditional surveys on issues such as responses, missing values and internal covariance (Davis, 1999; Smith, 2001; Stanton, 1998 and Walt et al., 2008). With the exception of Smith, the rest of the researchers found that despite differences in environments, the results were comparably equivalent. Other practical concerns include the effects of different browsers on the respondents, variation in computer expertise which may lead to errors and non-response, data security and privacy (Zanutto, 2001).

The implementation of mixed mode of surveys provides an alternative solution to the problems of traditional survey and online methods (de Leeuw, 2005, Dillman, et al., 2008). It can be done either concurrently or serially depending on the research objectives. It tends to increase response rate and coverage at affordable cost (Meckel et al., 2005), while at the same time it may increase the likelihood of measurement error because the survey question may appear somewhat differently under different mode (Christian and Dillman, 2004 and Lepkowski, 2008).

\section{Methodology and Research Design}

A survey on consumers was carried out to obtain data on their socio-economic background, attitude and preferences in buying fresh produce (fruits and vegetables) from the large scale retail stores (such as hypermarkets, supermarkets and departmental stores). Two methods were used; a face to face interview (FTF) and an online survey. The FTF interview was carried out in the months of July to November 2007. The study adopted convenience sampling method as a means of data collection procedure mainly from Peninsular Malaysia. A five-point Likert Scale was used to measure the magnitude of the consumers' attitude towards the store's marketing strategies for fresh fruits and vegetables. The consumers interviewed were from major towns in Malaysia, i.e., Kuala Lumpur, Petaling Jaya, Johor Baharu, Ipoh and Penang. The total number of responses was 452.

An online survey was carried out using the same set of questionnaire (with some modification according to the web's requirement) on www.utusan.com.my between $4^{\text {th }}$ until $21^{\text {st }}$ December 2007. This survey managed to obtain responses from Malay respondents from various locations in Malaysia. Another online survey is being carried out at www.thestar.com.my (from 18 February - 25 February 2008). The two web sites represent the most popular online newspapers in Malaysia. The total number of responses was 1,012. The study set to test the following two hypotheses:

$\mathrm{H}_{\mathrm{o}} 1$ : These is no significance difference in the socio-economic profiles of the two sets of respondents (FTF and internet survey).

$\mathrm{H}_{0} 2$ : These is no significance difference in perceptions towards the marketing strategies of the large scale stores between the two types of respondents (FTF and internet survey). 
To test the differences in means, the study utilises t, chi-squared and $\mathrm{Z}$ tests statistics depending on the types of scales and number of samples. Factor analysis was used to explore and reveal the hidden dimensions of a set of variables used in this study, thereby illustrating the relationships between the underlying factors and the observed variables. Only factors with Eigenvalue greater than one are consider for this methodology, which indicates that the extracted factors explain more variance than a single variable (Hair et al., 1998).

\section{Discussion of Findings}

\subsection{Socio-economic Profile}

Table 1 provides the test results of mean differences of the socio-economic variables of the two groups while Table 2 provides their frequency distributions. The t-values and chi-square statistics indicate that with the exception of "gender", there were significant differences in the means of other variables (age, education, marital status, ethnic, occupation and income). These suggest that the two samples are statistically different in terms of profile. The average age of the online respondents was 31.9 years (with S.D.=7.7) compared to the FTF (mean=35.9, S.D.=12.2). FTF respondents were well distributed among the age groups while more than $90 \%$ of the online respondents were below 44 years old. More than two thirds (68.1\%) of the online respondents were married compared $35.8 \%$ to the FTF's. Malay respondents were predominant in the online survey $(92.9 \%)$ compared to FTF $(65.7 \%)$. Almost half of the internet respondents owned businesses while about $40 \%$ of the FTF respondents worked with private companies. In terms of income, a total of $36 \%$ of the online respondents earned more than RM3,000 per month compared to $14 \%$ in the case of to FTF.

\subsection{Attitude towards Stores' Marketing Strategies}

Tables $3-5$ present the respondents' perception towards the stores' marketing strategies on fresh fruits and vegetables as well other general services and facilities provided to customers. On pricing policies, the t-tests show significant difference in the means of both groups. The FTF group indicated higher mean scores on all statements on pricing strategies. However, in terms of product policy, there was a significant difference between the two groups with regards to statement such as "The store provides imported produce", "Good product presentation", "Minimum searching cost" and "Variety of products that meet my requirements". The mean scores by the online group were higher compared to FTF's particularly on the low searching cost (4.0) and variety of products under one roof (4.07). These findings are not surprising in view of the "younger" and IT-savvy characteristics of the online respondents which put higher emphasis on the importance of information and shopping time.

In terms of promotional strategies, the two groups showed differences in opinion towards promotional strategies of the stores. The mean scores for the two groups differed significantly for statements such as "Seasonal promotion", "The travel cost is low", "Public transportation is available", and "Can visit other shops nearby" (Table 4). The two groups also showed significant mean differences in statements such as "Friendly service", "After sales service", "Can buy produce in bulk" and "Pleasant shopping environment" (Table 5).

\subsection{Factor Analysis}

The factor analysis on both samples generated eight major factors for the FTF group compared to six factors for the online respondents (Tables 6-9). The order of the first three factors generated for the two groups were similar, they were: "customer-centric product policy", "conducive shopping environment" and "customer loyalty programme". As for the FTF group, the other factors that drove them to by from the large scale retailers were, "high quality produce", "location advantage", "efficient customer services", "fair and reasonable pricing" and "purchasing advantage". However as for the internet respondents, two factors were omitted - "high quality produce" and "purchasing advantage". In the case of FTF, the eight factors accounted for $64.2 \%$ of the total variance explained while the six factors accounted for $67.9 \%$ for the online results. The reliability test of the online group was marginally higher than the FTF (Table 9). These findings suggest that there appear to be little differences between the two groups of respondents in terms of factors that lead them to buy FFVs from the large scale retailers.

\section{Conclusion}

The study utilises a parallel mixed mode surveys (face to face interview and an online survey) on a quest to examine the Malaysian consumers' attitude and preference in buying fresh produce (fruits and vegetables) from the large retail stores. While holding other procedures remain the same (hypotheses testing and empirical analyses), the above findings show that the two samples are different in terms of their socio-economic variables particularly age, education, ethnic, income and occupation. There is a marginal difference in terms of attitudinal attributes of the two groups towards the marketing strategies of the retail stores. The online group seems to value relatively more on the low searching cost of information about the produce and the availability of imported and a variety of produce sold in 
the stores. The factor analysis indicates a minor difference in terms of major factors underpinning their attitude towards the large scale stores. This exercise confirms the claim that there exists a sample bias if one utilises online survey. However, the mixed mode of survey proves a useful strategy for the research as it brings a number of advantages mentioned in the literature such as inexpensive, wider coverage and efficiency. The online survey complements the face to face interview as it captures the "younger" market nationwide and bigger coverage of samples, which would have not been possible with the time and resource constraints faced by the researchers.

\section{References}

Borkan, B. (2010). The mode effect in mixed-mode surveys: Mail and web surveys, Social Science Computer Review, August, Vol. 28, No. 3, pp. 371-380.

Christian, L. M. and Dillman, D. A. (2004). The influence of symbolic and graphical language manipulations on answers to paper self-administered questionnaires, Public Opinion Quarterly, Vol. 68 No.1, pp. 57-80. http://dx.doi.org/10.1093/poq/nfh004

Davis, Robert, N. (1999). Web-based administration of a personality questionnaire: Comparison with traditional methods, Behavior Research Methods, Instruments, and Computers, Vol. 31, No. 4, pp. 572-77. http://dx.doi.org/10.3758/BF03200737

de Leeuw, E. D. (2005). "To mix or not to mix data collection modes in surveys", The Journal of Official Statistics, Vol. 21 No. 2, pp. 233-255.

Dillman, D. A., et al. (2008). Response rate and measurement differences in mixed mode surveys using mail, telephones, interactive voice and the internet [Online] Available: http://www.sesrc.wsu.edu/dillman/papers/ResponseRateandMeasurement.pdf [September 29, 2011]

Dillman, D. A. (2000). Mail and internet surveys: The tailored design method. $2^{\text {nd }}$. ed., New York: John Wiley \& Sons.

FAOb. (2005). Spotlight: Farmers and supermarkets in Asia [Online] Available: www.fao.org/ag/magazine/0505sp1.htm (April 10, 2010)

Forest E. (1999). Internet Marketing Research. Sydney: McGraw-Hill.

Hair, J. F., Anderson, Rolph E. and Tatham, Ronald L. Black. (1998). Multivariate Data Analysis, 5th Edition, New York: Prentice Hall.

Jarvis, S. (2002). CMOR finds survey refusal rates still rising, Marketing News, 4 February, American Marketing Association, Chicago, IL, p4.

Kaye, B.K. and Johnson T.J. (1999). Research methodology: Taming of the cyber-frontier, Social Science Computer Review, Vol. 17 No. 3, pp.323-337.

Lepkowski, J. et al. (2008). Advances in Telephone Survey Methodology, New York:Wiley-Interscience.

Meckel, M., Walters, D. and Baugh, P. (2005). Mixed mode surveys using mail and web questionnaires, The Electronic Journal of Business Research Methodology, Vol.3 No.1, pp.69-80 [Online] Available: http://www.ejbrm.com/vol3/v3-i1/v3-i1-art6-meckel.pdf. [September 28, 2011]

Moss, J. and Hendry, G. (2002). Use of electronic surveys in course evaluation, British Journal of Educational Technology, Vol. 33 No. 5, pp.583 - 592. http://dx.doi.org/10.1111/1467-8535.00293

Nesbary, Dale. (2000). The taxation of Internet commerce: A state of the art review. Social Science Computer Review, Vol. 18 No.1. http://dx.doi.org/10.1177/089443930001800102

Payne, Stanley, L. (1964). Combination of survey methods, Journal of Marketing Research, Vol. 1, No. 2, pp. 61-62. http://dx.doi.org/10.2307/3149923

Petit, F. A. (1999). "Exploring the use of the world wide web as a psychology data collections tool". Computers in Human Behaviour, Vol.16, pp. 67-71. http://dx.doi.org/10.1016/S0747-5632(98)00033-8

Selltiz, C. et al. (1962). Research Methods in Social Relations. New York: Holt, Rinehart and Winston.

Smith, T. W. (2001). Are representative Internet surveys possible? [Online] Available: http://www.statcan.ca/english/freepub/11-522-XIE/2001001/session18/s18d.pdf. [ September 26, 2008]

Solomon, D. J. (2001). Conducting web-based surveys. Practical assessment, Research and Evaluation, Vol. 7 No. 19. [Online] Available: http://PAREonline.net/getvn.asp?v=7\&n=19 [September 26, 2011] 
Stanton, Jeffrey M. (1998). An empirical assessment of data collection using the internet, Personnel Psychology, Vol. 51, pp. 709-25. http://dx.doi.org/10.1111/j.1744-6570.1998.tb00259.x

Walt, N., Atwood, K., and Mann, A. (2008). Does survey medium affect responses? An exploration of electronic and paper surveying in British Columbia Schools, Journal of Technology, Learning and Assessment, Vol. 6 No. 7 [Online] Available: http://www.jtla.org [ September 26, 2008]

Weible, R. and Wallace J. (1998). "Cyber research: The impact of the internet on data collection”, Market Research, Fall, Vol. 10 No. 3, pp. 19-31.

Zikmund, W. G. (2003). Business Research Methods, 7th ed., Cincinnati: OH Thomson

Zanutto, E. (2001). Web and email surveys, [Online] Available: http://www-stat.wharton.upenn.edu/ Zanutto/Annenberg2001/docs/websurveys01.pdf [September 20, 2011]

Table 1. Mean Comparison

\begin{tabular}{|c|c|c|c|c|c|c|}
\hline \multirow{2}{*}{ Item } & \multicolumn{2}{|c|}{ FTF } & \multicolumn{2}{|c|}{ Online } & \multirow{2}{*}{$\begin{array}{c}\text { T-test / } \\
\text { Chi- square }\end{array}$} & \multirow{2}{*}{ Prob. } \\
\hline & Mean & S.D. & Mean & S.D. & & \\
\hline Gender & - & - & - & - & 0.837 & 0.360 \\
\hline Age (years) & 35.96 & 12.201 & 31.91 & 7.797 & 6.475 & 0.000 \\
\hline Marital status & - & - & - & - & 3.242 & 0.001 \\
\hline Ethnic & - & - & - & - & 7.158 & 0.000 \\
\hline Education & - & - & - & - & 3.128 & 0.001 \\
\hline Occupation & - & - & - & - & 17.458 & 0.000 \\
\hline Income (RM) & 1,746 & 1,375 & 2,705 & 1,934 & -9.783 & 0.000 \\
\hline
\end{tabular}

Note: FTF - Face to Face 
Table 2. Socio-economic Profile of Respondents

\begin{tabular}{|c|c|c|c|c|}
\hline \multirow{2}{*}{ Item } & \multicolumn{2}{|l|}{ FTF } & \multicolumn{2}{|l|}{ Online } \\
\hline & Frequency & $\%$ & Frequency & $\%$ \\
\hline \multicolumn{5}{|l|}{ Gender } \\
\hline Male & 114 & 25.2 & 455 & 45.0 \\
\hline Female & 338 & 74.8 & 556 & 55.0 \\
\hline Total & 452 & 100 & 1011 & 100 \\
\hline \multicolumn{5}{|l|}{ Age } \\
\hline$<24$ years & 99 & 21.9 & 149 & 14.8 \\
\hline $25-34$ & 118 & 26.1 & 547 & 54.4 \\
\hline $35-44$ & 113 & 25.0 & 221 & 22.0 \\
\hline $45-54$ & 89 & 19.7 & 80 & 8.0 \\
\hline$>55$ years & 33 & 7.3 & 8 & 0.8 \\
\hline Total & 452 & 100 & 1005 & 100 \\
\hline \multicolumn{5}{|l|}{ Marital status } \\
\hline Single & 61 & 61.3 & 320 & 31.9 \\
\hline Married & 276 & 35.8 & 6833 & 68.1 \\
\hline Divorced/separated & 13 & 2.9 & 0 & 0.0 \\
\hline Total & 450 & 100 & 1003 & 100 \\
\hline \multicolumn{5}{|l|}{ Ethnic } \\
\hline Malay & 297 & 65.7 & 934 & 92.9 \\
\hline Chinese & 136 & 30.1 & 16 & 1.6 \\
\hline Indian & 15 & 3.3 & 28 & 2.8 \\
\hline Others & 4 & 0.9 & 27 & 2.7 \\
\hline Total & 452 & 100 & 1005 & 100 \\
\hline \multicolumn{5}{|l|}{ Education } \\
\hline Primary education & 44 & 9.8 & 223 & 31.7 \\
\hline Secondary education & 232 & 51.7 & 292 & 41.5 \\
\hline Tertiary education & 173 & 38.5 & 188 & 26.7 \\
\hline Total & 449 & 100 & 703 & 100 \\
\hline \multicolumn{5}{|l|}{ Occupation } \\
\hline Public sector & 57 & 12.9 & 354 & 35.2 \\
\hline Own business & 51 & 11.5 & 497 & 49.4 \\
\hline Private sector & 179 & 40.4 & 30 & 3.0 \\
\hline Student & 45 & 10.2 & 88 & 8.7 \\
\hline Not working & 89 & 20.1 & 16 & 1.6 \\
\hline Others & 22 & 5.0 & 21 & 2.1 \\
\hline Total & 443 & 100 & 1006 & 100 \\
\hline \multicolumn{5}{|l|}{ Income } \\
\hline$<$ RM 999 & 87 & 27.0 & 98 & 9.8 \\
\hline RM 1,000 - RM 1,999 & 122 & 37.9 & 213 & 21.3 \\
\hline RM 2,000 - RM 2,999 & 68 & 21.1 & 327 & 32.6 \\
\hline RM 3,000 - RM 3,999 & 28 & 8.7 & 190 & 19.0 \\
\hline$>$ RM 4,000 & 17 & 5.3 & 174 & 17.4 \\
\hline Total & 322 & 100 & 1002 & 100 \\
\hline
\end{tabular}

Note: USD1=RM3.2 
Table 3. Consumer Attitude towards Pricing and Product Strategies

\begin{tabular}{|l|l|c|c|c|c|c|c|c|c|}
\hline \multirow{2}{*}{$\begin{array}{l}\text { No } \\
\cdot\end{array}$} & Statement & \multicolumn{2}{|c|}{ FTF } & \multicolumn{3}{|c|}{ Online } & \multicolumn{2}{|c|}{ Difference } & \\
\cline { 2 - 9 } & & SD & Mean & SD & Mean & SD & T test & Prob. \\
\hline \multicolumn{2}{|l|}{ Pricing } & & & & & & & & \\
\hline 1 & Prices are cheap & 3.25 & 0.851 & 3.15 & 0.966 & 0.10 & -0.115 & 2.107 & 0.035 \\
\hline 2 & Prices are transparent from & 3.92 & 0.767 & 3.67 & 1.069 & 0.25 & -0.302 & 4.953 & 0.000 \\
\hline 3 & $\begin{array}{l}\text { Prices available } \\
\text { catalogue }\end{array}$ & 0.960 & 3.08 & 1.197 & 0.24 & -0.237 & 3.980 & 0.000 \\
\hline 4 & Prices are reasonable & 3.49 & 0.830 & 3.33 & 0.908 & 0.16 & -0.078 & 3.339 & 0.000 \\
\hline Product & & & & & & & & \\
\hline 5 & Produce are fresh & 3.66 & 0.864 & 3.56 & 0.888 & 0.10 & -0.024 & 2.097 & 0.036 \\
\hline 6 & $\begin{array}{l}\text { Produce are consistently of } \\
\text { high quality }\end{array}$ & 3.28 & 0.899 & 3.36 & 0.880 & -0.08 & 0.019 & -1.615 & 0.107 \\
\hline 7 & Variety of produce & 3.84 & 0.788 & 3.90 & 0.864 & -0.06 & -0.076 & -1.217 & 0.224 \\
\hline 8 & Imported produce & 3.58 & 0.900 & 3.90 & 0.803 & -0.32 & 0.097 & -6.408 & 0.000 \\
\hline 9 & $\begin{array}{l}\text { Pre-packed, ready for } \\
\text { cooking vegetables }\end{array}$ & 3.64 & 0.848 & 3.82 & 0.802 & -0.18 & 0.046 & -3.801 & 0.000 \\
\hline 10 & Good product presentation & 3.80 & 0.774 & 3.82 & 0.817 & -0.02 & -0.043 & -0.505 & 0.613 \\
\hline 11 & $\begin{array}{l}\text { Variety of products under one } \\
\text { roof }\end{array}$ & 4.00 & 0.712 & 4.07 & 0.833 & -0.07 & -0.121 & -1.702 & 0.089 \\
\hline 12 & Minimum searching cost & 3.80 & 0.873 & 4.00 & 0.852 & -0.20 & 0.021 & -4.113 & 0.000 \\
\hline 13 & $\begin{array}{l}\text { Various grades to meet my } \\
\text { requirements }\end{array}$ & 3.67 & 0.826 & 3.77 & 0.886 & -0.10 & -0.06 & -2.061 & 0.04 \\
\hline
\end{tabular}

Note: SD is Standard Deviation

Table 4. Consumer Attitude towards Promotion and Location Strategies

\begin{tabular}{|c|l|c|c|c|c|c|c|c|c|}
\hline \multirow{2}{*}{$\begin{array}{l}\text { No } \\
\cdot\end{array}$} & Statement & \multicolumn{2}{|c|}{ FTF } & \multicolumn{2}{|c|}{ Online } & \multicolumn{2}{c|}{ Difference } & \multirow{2}{*}{ T test } & Prob. \\
\cline { 2 - 9 } & Mean & SD & Mean & SD & Mean & SD & \\
\hline Promotion & & & & & & & & \\
\hline 14 & Promotional benefits & 3.65 & 0.876 & 3.56 & 0.976 & 0.09 & -0.1 & 1.829 & 0.068 \\
\hline 15 & Seasonal promotion & 3.92 & 0.686 & 3.79 & 0.684 & 0.13 & -0.178 & 3.255 & 0.001 \\
\hline 16 & Brochure & 3.73 & 0.811 & 3.72 & 0.942 & 0.01 & -0.131 & 0.061 & 0.951 \\
\hline 17 & $\begin{array}{l}\text { Consumers } \\
\text { programme }\end{array}$ & 3.72 & 0.872 & 3.76 & 1.002 & -0.04 & -0.13 & -0.671 & 0.503 \\
\hline Location loyalty & The travel cost is low & 3.49 & 0.912 & 3.61 & 1.034 & -0.12 & -0.122 & -2.35 & 0.019 \\
\hline 18 & $\begin{array}{l}\text { The retail premise located } \\
\text { near my place }\end{array}$ & 3.56 & 0.944 & 3.67 & 1.042 & -0.11 & -0.098 & -1.973 & 0.049 \\
\hline 20 & $\begin{array}{l}\text { Public transportation is } \\
\text { available }\end{array}$ & 3.24 & 0.982 & 3.03 & 1.257 & 0.21 & -0.275 & 3.305 & 0.001 \\
\hline 21 & $\begin{array}{l}\text { Can visit other shops } \\
\text { nearby }\end{array}$ & 3.56 & 0.855 & 3.67 & 0.971 & -0.11 & -0.116 & -2.343 & 0.019 \\
\hline
\end{tabular}


Table 5. Consumer Attitude towards Services, Facilities and Shopping Environment

\begin{tabular}{|c|c|c|c|c|c|c|c|c|c|}
\hline \multirow[b]{2}{*}{ No. } & \multirow[b]{2}{*}{ Statement } & \multicolumn{2}{|c|}{ FTF } & \multicolumn{2}{|c|}{ Online } & \multicolumn{2}{|c|}{ Difference } & \multirow[b]{2}{*}{ T test } & \multirow[b]{2}{*}{ Prob. } \\
\hline & & Mean & SD & Mean & SD & Mean & SD & & \\
\hline \multicolumn{10}{|c|}{ Services } \\
\hline 22 & Friendly service & 3.51 & 0.846 & 3.37 & 0.868 & 0.14 & -0.022 & 3.065 & 0.002 \\
\hline 23 & Fast transaction & 3.36 & 0.869 & 3.31 & 0.909 & 0.05 & -0.04 & 0.982 & 0.326 \\
\hline 24 & After sales service & 2.85 & 1.080 & 2.73 & 1.091 & 0.12 & -0.011 & 2.012 & 0.045 \\
\hline 25 & Can buy produce in bulk & 3.44 & 0.827 & 3.54 & 0.863 & -0.10 & -0.036 & -2.085 & 0.037 \\
\hline 26 & $\begin{array}{l}\text { Can pay using credit } \\
\text { cards }\end{array}$ & 3.91 & 0.949 & 3.93 & 0.974 & -0.02 & -0.025 & -0.343 & 0.732 \\
\hline \multicolumn{10}{|c|}{ Facilities and Shopping Environment } \\
\hline 27 & $\begin{array}{l}\text { Facilities for consumers' } \\
\text { convenience }\end{array}$ & 4.07 & 0.734 & 4.10 & 0.873 & -0.03 & -0.139 & -0.669 & 0.504 \\
\hline 28 & $\begin{array}{l}\text { Air-conditional } \\
\text { environment }\end{array}$ & 4.17 & 0.716 & 4.21 & 0.823 & -0.04 & -0.107 & -0.804 & 0.422 \\
\hline 29 & Good hygiene condition & 3.96 & 0.809 & 3.98 & 0.874 & -0.02 & -0.065 & -0.437 & 0.662 \\
\hline 30 & Spacious & 3.99 & 0.812 & 3.92 & 0.848 & 0.07 & -0.036 & 1.44 & 0.150 \\
\hline 31 & \begin{tabular}{|ll}
$\begin{array}{l}\text { Pleasant } \\
\text { environment }\end{array}$ & shopping \\
\end{tabular} & 4.17 & 0.795 & 4.07 & 0.893 & 0.10 & -0.098 & 2.001 & 0.046 \\
\hline
\end{tabular}

Table 6. Comparison of Factors Identified

\begin{tabular}{|l|l|l|l|}
\hline Factor & FTF & Factor & Online \\
\hline 1 & Customer-centric product policy & 1 & Customer-centric driven policy \\
\hline 2 & Conducive shopping environment & 2 & Conducive shopping environment \\
\hline 3 & Customer loyalty programme & 3 & Customer loyalty programme \\
\hline 4 & High produce quality & 4 & Location advantage \\
\hline 5 & Location advantage & 5 & Fair and reasonable pricing \\
\hline 6 & Efficient customer services & 6 & Efficient customer services \\
\hline 7 & Fair and reasonable pricing & & \\
\hline 8 & Purchasing advantage & & \\
\hline
\end{tabular}


Table 7. Factor Analysis on FTF Respondents

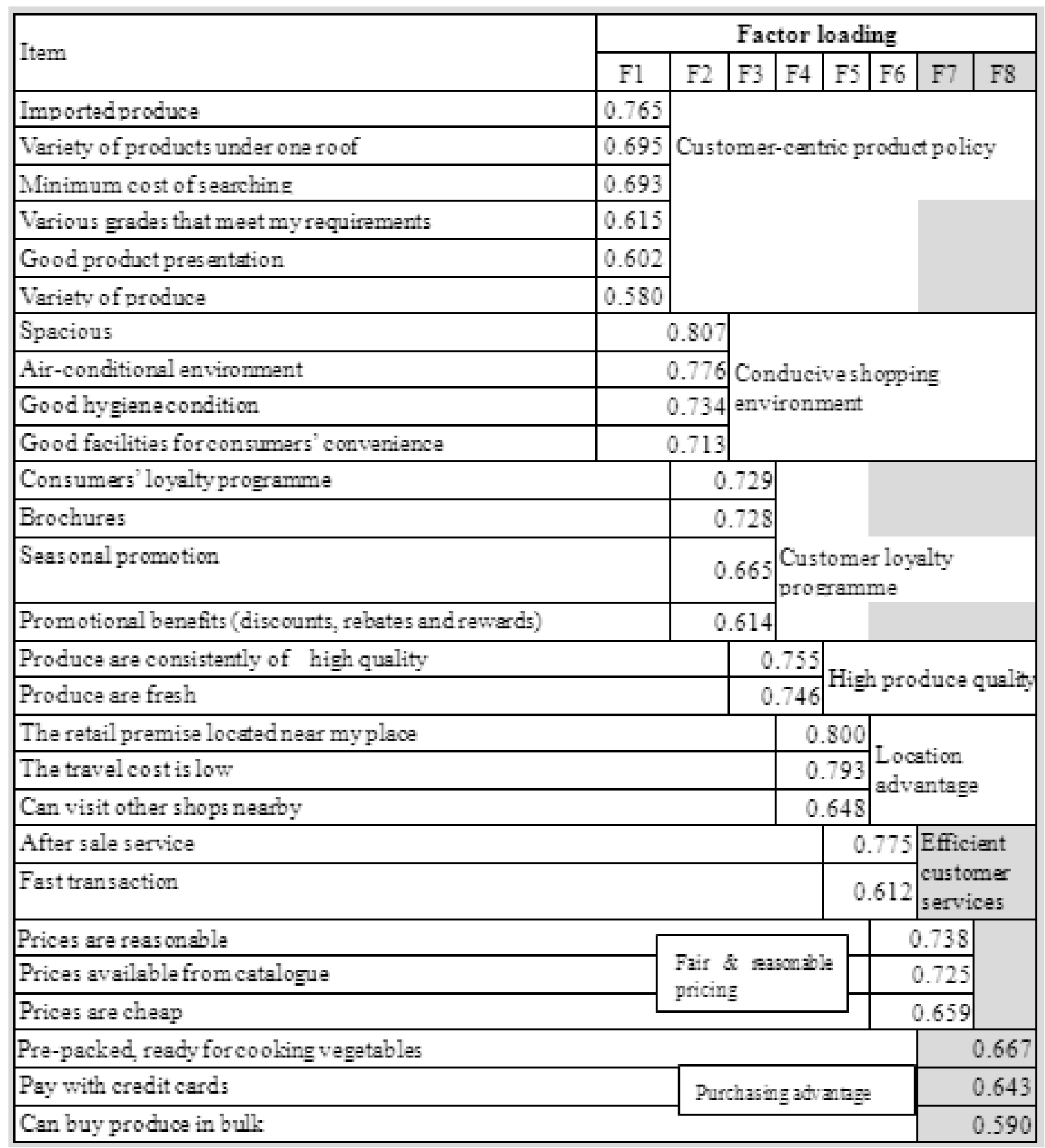

Bartlett's Test of Sphericity: Approx. Chi-Square $=4.925 E 3, \mathrm{df}=435$, Sig $=0.0001$

Kaiser-Meyer-Olkin Measure of Sampling Adequacy=.886 
Table 8. Factor Analysis on Online Respondents

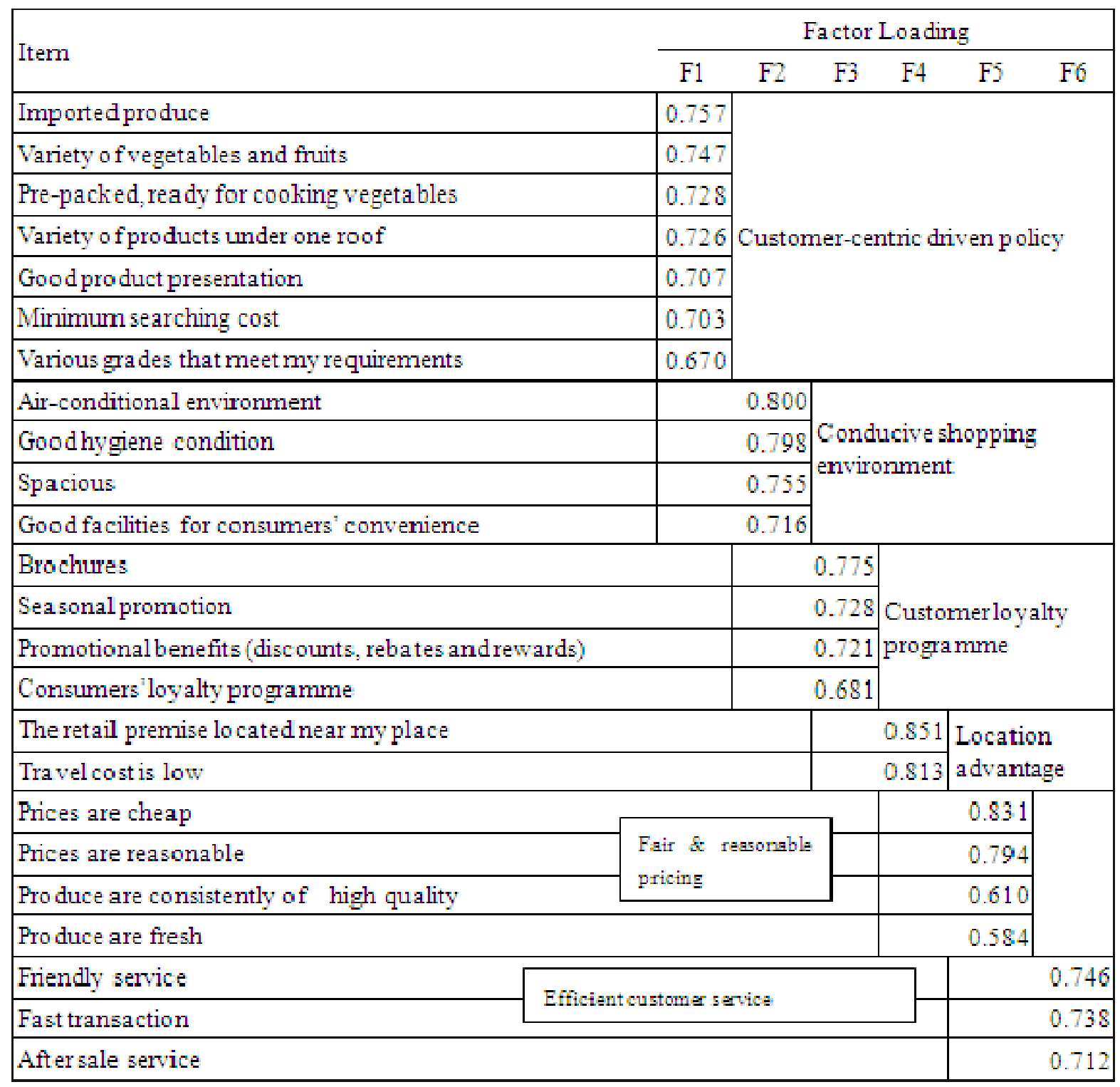

Bartlett's Test of Sphericity: Approx. Chi-Square $=1.512 \mathrm{E} 4 \mathrm{df}=351, \mathrm{Sig}=0.0001$

Kaiser-Meyer-Olkin Measure of Sampling Adequacy $=0.929$

Table 9. Comparison of Statistics of Factor Analysis

\begin{tabular}{|c|c|c|c|c|c|c|c|c|}
\hline \multirow{2}{*}{ Factor } & \multicolumn{3}{|c|}{ FTF } & \multicolumn{4}{|c|}{ Online } \\
\cline { 2 - 9 } & Eigenvalue & $\begin{array}{c}\text { \% of } \\
\text { variance }\end{array}$ & Cumulative \% & $\begin{array}{l}\text { Reliability } \\
\text { Test }\end{array}$ & Eigenvalue & $\begin{array}{c}\text { \% of } \\
\text { variance }\end{array}$ & Cumulative \% & $\begin{array}{l}\text { Reliability } \\
\text { Test }\end{array}$ \\
\hline 1 & 8.561 & 28.538 & 28.538 & 0.830 & 10.564 & 39.127 & 39.127 & 0.905 \\
\hline 2 & 2.140 & 7.133 & 35.671 & 0.852 & 2.170 & 8.039 & 47.166 & 0.903 \\
\hline 3 & 1.867 & 6.223 & 41.894 & 0.787 & 1.776 & 6.579 & 53.745 & 0.857 \\
\hline 4 & 1.850 & 6.166 & 48.060 & 0.756 & 1.428 & 5.288 & 59.033 & 0.875 \\
\hline 5 & 1.492 & 4.972 & 53.032 & 0.704 & 1.293 & 4.790 & 63.822 & 0.825 \\
\hline 6 & 1.255 & 4.183 & 57.215 & 0.611 & 1.123 & 4.159 & 67.981 & 0.789 \\
\hline 7 & 1.103 & 3.678 & 60.893 & 0.691 & & & & \\
\hline 8 & 1.007 & 3.355 & 64.249 & 0.565 & & & & \\
\hline
\end{tabular}

